\title{
Variation in Lysine Content in Durum Wheat (Triticum durum L.) Genotypes under Irrigation Conditions
}

\author{
Himani $^{1 *}$, Shashi Madan ${ }^{1}$ and S.K. Sethi ${ }^{2}$ \\ ${ }^{1}$ Department of Chemistry and Biochemistry, COBS\&H, CCS Haryana Agricultural \\ University, Hisar-125004, Haryana, India \\ ${ }^{1}$ Department of Genetics and Plant Breeding, COA, CCS Haryana Agricultural University, \\ Hisar-125004, Haryana, India \\ *Corresponding author
}

\section{A B S T R A C T}

Keywords

Amino acids,

Durum wheat,

Lysine, Nutrition,

Quality

Article Info

Accepted:

26 December 2017

Available Online:

10 January 2018
The present investigation was carried out to analyze the variation in lysine content in thirty six durum wheat genotypes under irrigation conditions. The cereal proteins are low in lysine one of the essential amino acids that cannot be synthesized by humans and must therefore be obtained entirely from dietary sources. Thus, lysine content constitutes an important feature for defining the nutritive value of flour obtained from cereals. Lysine content was found maximum in WHD $954(3.53 \mathrm{~g} / 16 \mathrm{~g} \mathrm{~N})$ followed by UAS $448(3.52 \mathrm{~g} / 16 \mathrm{~g} \mathrm{~N})$ and minimum was observed in MACS 3944 (2.05 $\mathrm{g} / 16 \mathrm{~g} \mathrm{~N}$ ). These genotypes were found promising and may be used in crossing programme in order to improve grain quality.

\section{Introduction}

Wheat is the world's most widely cultivated food plant which is used for the production of a wide range of food products. Durum wheat is the main raw material for pasta products due to its balanced components that interact during processing, allow receiving products with desired quality. It is tetraploid wheat known for its hardness, protein, intense yellow colour, nutty flavor and excellent cooking qualities. The availability of nutrients from a particular food depends on its chemical composition. The pasta quality of durum wheat is influenced mainly by the physical and biochemical properties of wheat kernels, which are in turn determined by genotype, environment and their interactions (Taghouti et al., 2010). The quality of wheat is largely dependent upon its chemical composition which is influenced by genetic, environmental factors and processing conditions. Grain protein content is considered as the main characteristic of durum wheat grain quality (Ottman et al., 2000; Clarke, 2001). Protein content in durum wheat is higher than bread 
wheat and is one of the main factors influencing the functional properties of flour (Rojo et al., 1986; Tiwari et al., 2008). The protein quality depends upon the balance of amino acid composition in the wheat grains (Li and Zhang, 2000; Liu et al., 2002). The nutritional quality of a protein can be measured by a variety of criteria but in essence it is the relative amounts and the balance of essential amino acids in the dietary protein. Quality improvement has been a great challenge in wheat research.

Constant efforts are being made all over the world to improve/combine quality with yield along with biotic and abiotic stresses so that the developed material could be released as a variety. Amino acid composition is an important feature in determining the nutritional value of durum wheat grain for human and animal diets. The cereal proteins are low in lysine one of the essential amino acids that cannot be synthesized by humans and must therefore be obtained entirely from dietary sources. Thus, lysine content constitutes an important feature for defining the nutritive value of flour obtained from cereals (Luis et al., 2007). The possibility of engineering of metabolic pathway for improving lysine content in seeds has increased with the understanding of the genes involved in its biosynthesis and degradation. The development of product specific varieties depends on the knowledge of quality requirements of different end use products and the genetic components controlling different quality traits. Thus, present study helps in identification of superior genotypes rich in lysine content.

\section{Materials and Methods}

The crop was raised during rabi season under irrigated conditions in the field of Wheat and Barley Section, Department of Genetics and Plant Breeding, CCS Haryana Agricultural
University, Hisar (Haryana) identify durum wheat genotypes superior in lysine content. The experiment was laid out in Randomized Block Design (RBD) with three replications. The varieties were sown with a plot size of $6 \times 1.20$ sq. meter. The experiment consists of 36 durum wheat genotypes including four checks (two bread and two durum wheat). The recommended cultural practices were carried out to raise good crop. The grains of durum wheat genotypes were collected after harvest and stored in paper bags for the estimation of lysine content. Total lysine was estimated as per the method described by Mertz et al., (1975). Hundred mg of finely ground defatted grain sample was transferred into a glass vial and $5 \mathrm{ml}$ of papain solution was added and incubated at $65^{\circ} \mathrm{C}$. The hydrolyzed samples were then centrifuged it at $3000 \mathrm{rpm}$ for 5 minutes and $0.1 \mathrm{ml}$ of 2-chloro-3, 5dinitropyrindine solution was added. Five $\mathrm{ml}$ of $1.2 \mathrm{~N} \mathrm{HCl}$ and $5 \mathrm{ml}$ of ethyl acetate were added and the upper layer was discarded. The absorbance of aqueous phase containing $\varepsilon$ DNPyr-lysine was read at $390 \mathrm{~nm}$. The amount of lysine content $(\mathrm{g} / 16 \mathrm{~g} \mathrm{~N})$ of the samples was then calculated by referring to a standard curve of L-lysine $\mathrm{HCl}$ as the standard (0-200 $\mu \mathrm{g}$ lysine/ml).

\section{Results and Discussion}

The nutritional quality of wheat relies on amino acid composition; therefore evaluation of lysine in various genotypes might reveal the relative importance to nutritional status which will be used to improve the already existing genotypes further through specified breeding programmes. The cereal proteins are low in lysine which is one of the essential amino acids that cannot be synthesized by human beings. Lysine content constitutes an important feature for defining the nutritive value of flour obtained from cereals. The lysine content among various genotypes was estimated. 
Fig.1 Total lysine $(\mathrm{g} / 16 \mathrm{~g} \mathrm{~N})$ in durum wheat genotypes

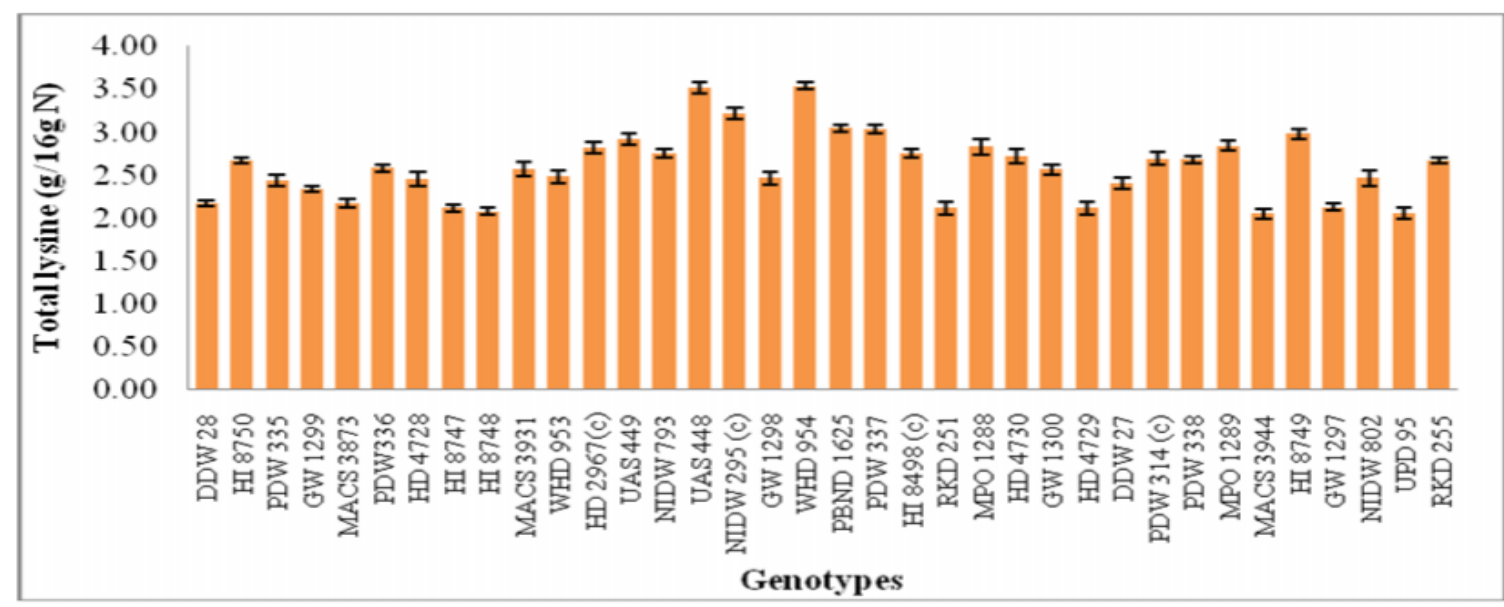

C.D. at 5 per cent $=0.171$

Total lysine of durum wheat genotypes is depicted in Figure 1. It ranged from 2.05 to $3.54 \mathrm{~g} / 16 \mathrm{~g} \mathrm{~N}$ with an overall mean value of $2.59 \mathrm{~g} / 16 \mathrm{~g} \mathrm{~N}$. Highest level of total lysine was found in WHD $954(3.54 \mathrm{~g} / 16 \mathrm{~g} \mathrm{~N})$ followed by UAS $448(3.52 \mathrm{~g} / 16 \mathrm{~g} \mathrm{~N})$ and lowest was observed in MACS 3944 (2.05 $\mathrm{g} / 16 \mathrm{~g} \mathrm{~N}$ ).

The results of present investigation corroborate the previous reports of Rharrabti et al., (2001) and Luis et al., (2007). Hira et al., (1991) analyzed 19 wheat varieties for crude protein and available lysine. The mean values for crude protein and available lysine were 11.7 per cent and $2.43 \mathrm{~g}$ per $16 \mathrm{~g} \mathrm{~N}$, respectively.

The lysine content of protein of spring wheat, durum wheat, other wheat varieties, rye and triticale were analyzed and it was found that lysine content of $T$. durum, T. aestivum and rye ranged from $1.84-3.10 \mathrm{~g} / 16 \mathrm{gN}, 2.15$ $2.77 \mathrm{~g} / 16 \mathrm{gN}, \quad 2.55-4.26 / 16 \mathrm{gN}$, respectively (Lawrence et al., 1958; Villegas et al., 1970). The genotypes WHD 954 (3.53 g/16g N) and UAS 448 may be used in the breeding strategy to improve wheat quality by incorporating useful traits in future wheat genotypes.

\section{References}

Clarke, J.M. 2001. Improvement of durum wheat grain quality. Breeding. In: Durum wheat, semolina and pasta quality. Recent achievements and new trends. (Eds. Abecassis, J., Autran, J.C. and Feillet, P.). INRA, Paris. pp. 27-54.

Hira, C.K., Kocchar, A., Sadana, B.K. and Sharma, K.K. 1991. Protein, lysine, mineral and phenol contents of some Indian wheat (Triticum aestivum) varieties. J. Food Sci. Tech. 28(2): 112117.

Lawrence, J.M., Day, K.M., Huey, E. and Lee, B. 1958. Lysine content of wheat varieties, species and related genera. Cereal Chem. 35:169.

Li, W.H. and Zhang, D.H. 2000. The balance analysis of the amino acid content in seed filling period of wheat. Seed. 2: 21-23.

Liu, Y.P., Que, S.Y., Li, X.P., Lan, S.Q., Lie, Y.H. and Li, J.P. 2002. Protein content and amino acid composition and qualities of different blue and purple grain wheat. Acta. Agric. Boreali-Sin. 17: 103-107.

Luis, F., Moral, J.D., Rharrabti, Y., Martos, V. and Royo, C. 2007. Environmentally 
induced changes in amino acid composition in the grain of durum wheat grown under different water and temperature regimes in a Mediterranean environment. J. Agric. Food Chem. 55: 8144-8151.

Mertz, E.T., Jambunathan, R. and Misra, P.S. 1975. In: Protein Quality. Agric. Exp. Stn. Bull. No. 70 Purdue University, USA. pp.11.

Ottman, M.J., Doerge, T.A. and Martin, E.C. 2000. Durum grain quality as affected by nitrogen fertilization near anthesis and irrigation during grain fills. Agron. J. 92(5): 1035-1041.

Rharrabti, Y., Elhani, S., Vanessa, M.N. and Garcia del Moral, L. 2001. Protein and lysine content, grain yield, and other technological traits in durum wheat under Mediterranean conditions. $J$. Agric. Food Chem. 49: 3802-3807.

Rojo, G., Garcia, D.M. and Moral, L.F. 1986. Physiology of grain and protein yield in crops of bread wheat, durum wheat and triticale. Plant Breed. Abst. 58(4): 467.

Taghouti, M., Gaboun, F., Nsarellah, N., Rhrib, R., El-Haila, M., Kamar, F., Abbad- Andaloussi. And Udupa, S.M. 2010. Genotype x Environment interaction for quality traits in durum wheat cultivators adapted to different environments. Afr. J. Biotechnol. 9: 3054-3062.

Tiwari, R., Goutam, U., Singh, R., Rane, J. and Gupta, R.K. 2008. Grain quality parameters in high protein wheat genotypes at different locations and temperature regimes. J. Wheat Res. 2(1): 57-62.

Villegas, E., McDonald, C.E and Gilles, K.A. 1970. Variability in the lysine content of wheat, rye and triticale proteins. Ph.D. Thesis, Dept. Cereal Chem. Technol. State Univ. Fargo, North Dakota.

\section{How to cite this article:}

Himani, Shashi Madan and Sethi, S.K. 2018. Variation in Lysine Content in Durum Wheat (Triticum durum L.) Genotypes under Irrigation Conditions. Int.J.Curr.Microbiol.App.Sci. 7(01): 3204-3207. doi: https://doi.org/10.20546/ijcmas.2018.701.382 